sciendo Порівняльна професійна педагогіка 9(4)/2019 Comparative Professional Pedagogy 9(4)/2019

DOI: $10.2478 /$ rpp-2019-0038

$\mathrm{PhD}$ in Physical Education and Sport, Associate Professor, YURIY DUTCHAK

Khmelnytskyi National University

Address: 11 Instytuska St., Khmelnytskyi, 29016, Ukraine

E-mail: yrdutchak@ukr.net

$\mathrm{PhD}$ in Pedagogy, Associate Professor, LUDMILA KRAVCHUK

Address: 2 Yaroslav Mudryi St., Khmelnytskyi, 29000, Ukraine

E-mail: kravchuk_lst@ukr.net

\title{
SOME PECULIARITIES OF PROFESSIONAL TRAINING FOR FUTURE MASTERS IN PHYSICAL CULTURE IN THE REPUBLIC OF KAZAKHSTAN
}

\begin{abstract}
The analysis of legislative and regulatory framework regarding educational process in higher educational establishments of Kazakhstan allows to state that training of academic staff in physical culture and coaching personnel is done within "Physical culture and sport" specialty. There is no division into "Secondary education. Physical culture" and "Physical culture and sport". In the Republic of Kazakhstan, fundamental academic education in "Physical culture and sport" is obtained at graduate course. Curricula of the second level in "Physical culture and sport" are implemented by 9 higher educational establishments of various forms of ownership. Training at graduate course is done on the basis of higher educational curricula in two areas: academic and pedagogical (at least two years) and profile (at least one year), full-time only. Graduate-course program by academic and pedagogical area in "Physical culture and sport" in the Republic of Kazakhstan corresponds to graduatecourse program in "Secondary education. Physical culture" in Ukraine. Second-level educational program in "Physical culture and sport" includes cycles of basic and profile subjects that are further divided into components of a higher educational establishment and optional subjects. Overall volume of credits in this program is 120 ECTS. Upon completion of studies, students are awarded the degree of a master in pedagogical sciences in "Physical culture and sport". Completion of this curriculum provides formation of highly qualified, competitive academic and pedagogical staff needed at labor market, able to act professionally in any social and economic situations at a higher academic and pedagogical level.

Keywords: master, professional training, academic and pedagogical area, "Physical culture and sport" specialty, Republic of Kazakhstan.

\footnotetext{
АНАТОЦІЯ

Аналіз нормативно-правової бази, що стосується освітнього процесу у закладах вищої освіти Республіки Казахстан, дозволяє констатувати, що підготовка магістрів з фізичної культури відбувається в межах спечіальності «Фізична культура і спорт», поділу на спеціальності «Середня освіта. Фізична культура» та «Фізична культура і спорт» немає. У Республіиі Казахстан фундаментальну наукову освіту за спеиіальністю «Фізична культура $і$ спорт» отримують у магістратурі. Освітні програми другого рівня вищой освіти (магістерського) за спеиіальністю «Фізична культура і спорт» реалізуються дев 'ятьма закладами вищої освіти різних
} 
sciendo Порівняльна професійна педагогіка 9(4)/2019 Comparative Professional Pedagogy 9(4)/2019

форм власності. Підготовка у магістратурі здійснюється на базі освітніх програм вищої освіти за двома напрямами: науково-педагогічному з терміном навчання не менше двох років і профільному з терміном навчання не менше одного року. Освітня програма магістратури за науково-педагогічним напрямом спеціальності "Фізична культура і спорт» у Республіиі Казахстан відповідає освітній програмі магістратури спеціальності “Середня освіта. Фізична культура» в Україні. Освітня програма другого рівня за спеціальністю «Фізична культура і спорт» має ичикли базових та профільних дисциплін, які у свою чергу поділяються на обов'язкові компоненти закладу вищої освіти та вибіркові. Загальний обсяг кредитів за даною програмою складає 120 ECTS. По завершенню навчання магістрантам присвоюється академічна ступінь - магістр педагогічних наук за спеціальністю «Фізична культура і спорт». Засвоєння даної освітньої програми забезпечує формування висококваліфікованих, конкурентоспроможних науково-педагогічних кадрів, затребуваних на ринку прачі, здатних на високому науково-педагогічному рівні реалізовувати професійну діяльність в будь-яких сочіально-економічних умовах.

Ключові слова: магістр, професійна підготовка, науково-педагогічний напрям, спеиіальність «Фізична культура і спорт», Республіка Казахстан.

\section{INTRODUCTION}

The integration of Ukraine into European educational and scientific plane sets a number of requirements to training of specialists in the system of higher education. Undoubtedly, country's competitiveness in modern world depends on active development of education, science, new technologies, which is the key to high level and quality of life of its citizens.

For implementation of systematic changes in higher education, A. V. Svatyev (2014) draws attention to importance and necessity of analysis and implementation of foreign countries' leading experience within the context of higher physical culture education (p. 84).

Given the aforementioned, experience in training of future masters in former Soviet countries, systems of training and specialists (masters) attestation of which were formed within a single country is rather interesting and useful.

\section{THE AIM OF THE STUDY}

The aim of the article is to analyze and generalize experience in professional training of future secondary education masters in physical culture in the Republic of Kazakhstan.

\section{THEORETICAL FRAMEWORK AND RESEARCH METHODS}

The experience of organizing professional training of sports educators abroad was studied (Akhmetzhanov, Tusupbekov, \& Tileubergen; 2016 Humeniuk, 2017; Dereka, 2016; Svatyev, 2012; Pavelko, 2011; Sagintayeva, Hartly, Ekel, \& Zhakypova, 2018). It should be noted that scientists focused mainly on EU and US countries, and in the post-Soviet countries this issue was investigated in a non-systematic and fragmented manner.

Research methods are an analysis of references and documents; a method of systematic analysis; a method of comparison.

\section{RESULTS}

Present-day development of higher education in the Republic of Kazakhstan is primarily regulated by the law "On Education" (2007) and the State program of education development in the republic of Kazakhstan for 2011-2020 (2010). Realization of these legal acts envisages improvement of education competitiveness, development of human capital via assurance of quality education for stable economy growth on the basis of implementation of the Bologna declaration principles of European higher educational plane. 
sciendo Порівняльна професійна педагогіка 9(4)/2019 Comparative Professional Pedagogy 9(4)/2019

Starting from 2004, a multi-level structure of higher education and post-graduate education (undergraduate, graduate, $\mathrm{PhD}$ postgraduate course) have been implemented in the republic of Kazakhstan.

As stated by S. B. Akhmetzhanova (2016, p. 119), this structure is being implemented in 127 higher educational establishments of the republic, including 9 national, 32 state, 3 international, 13 non-civil, 14 joint-stock, and 56 private establishments (see Fig. 1).

Joint-stock higher educational establishments draw the biggest attention. They were formed due to transformation of national and state establishments into joint-stock companies with state's share in their statuary capital. As noted by A. K. Sygantayeva, this transformation is aimed at university's income increase (endowment fund, special purpose fund) and formation of a financial model approximated to world practice. Increase of financial activity transparency will be assured via presentation of an annual public accountability and audit. Higher educational establishments can independently select academic structure and laws on international cooperation and legal persons (Sygantayeva, 2018, p. 56). We may state that this type of establishments most comprehensively realizes principles of higher educational establishments' autonomy.

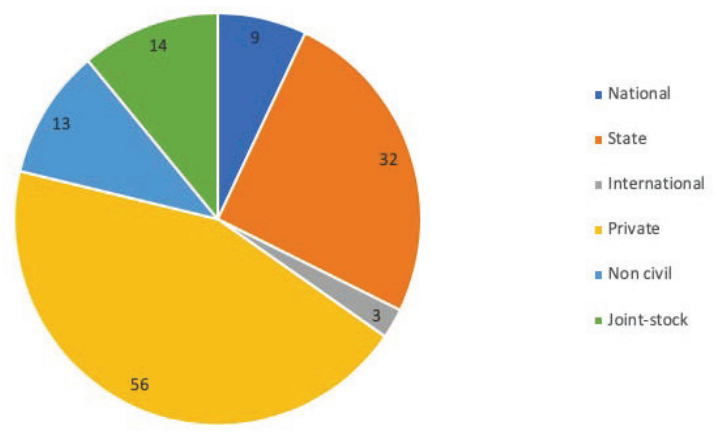

Fig. 1. Structure of higher educational establishments of the Republic of Kazakhstan

The following forms of higher education are used in the Republic of Kazakhstan:

- full-time - the most popular form that envisages compulsory attendance of lectures and seminars;

- part-time - students attend intensive classes two times a year. Duration of studies is one month, upon completion of which students pass exams.

- distance learning - is done via Internet. Students receive all necessary information and materials, tasks for independent work, online consultations via Internet. However, defense of thesis is done in a higher educational establishment (2018).

Basic subsystems of Kazakhstan's system of quality assurance are Independent agency for accreditation and rating (IQAR) and Independent agency for education quality assurance that have been acknowledged at international level. Starting from 2017, these agencies are members of European association for quality assurance in higher education (ENQA) (2019, p. 14).

Analysis of legislative and regulatory framework regarding educational process in higher educational establishments of the Republic of Kazakhstan allows to state that training of academic staff in physical culture and coaching personnel is done within "Physical culture and sport" specialty. There is no division into "Secondary education. Physical culture" and "Physical culture and sport". 
sciendo Порівняльна професійна педагогіка 9(4)/2019 Comparative Professional Pedagogy 9(4)/2019

Considering the topic of the research, analysis of professional training at the second (graduate) level in "Physical culture and sport" in the Republic of Kazakhstan draws big attention.

Graduate students obtain profound theoretical knowledge, skills in research and pedagogical work, as well as opportunity to prepare themselves for $\mathrm{PhD}$ course.

Training at graduate course is done in accordance with the Classifier of specialties of higher and post-graduate education in the Republic of Kazakhstan. It is done in two areas: profile; scientific and pedagogical (2012).

Normative duration of completing graduate-course program:

- at profile training - 1 year (for entrants from "Physical culture and sport");

- at profile training - 1.5 year (for entrants from non-profile specialties);

- at scientific and pedagogical training -2 years (2019).

The fact that education at graduate course in "Physical culture and sport" in the Republic Kazakhstan is done only in full-time form is rather interesting for Ukrainian higher educational establishments.

Based on data of the Statistics Committee of Ministry of National Economy of the Republic of Kazakhstan, graduate course in "Physical culture and sport" is realized in 9 higher educational establishments (see Table 1).

It should be noted that the number of higher educational establishments that have graduate course in "Physical culture and sport" is $8 \%$ from general number of establishments. At the same time, non-civil establishments were not taken into account as they train specialists for power structures.

Higher educational establishments that provide master's program

Table 1 in "Physical culture and sport" in Kazakhstan

\begin{tabular}{|c|l|c|}
\hline No & \multicolumn{1}{|c|}{ Name of a higher educational establishment } & Type of establishment \\
\hline 1 & Al-Farabi Kazakh National University & National \\
\hline 2 & Abai Kazakh National Pedagogical University & National \\
\hline 3 & L.N. Gumilyov Eurasian National University & State \\
\hline 4 & $\begin{array}{l}\text { Sarsen Amanzholov East Kazakhstan State } \\
\text { University }\end{array}$ & State \\
\hline 5 & M. Kozybayev North Kazakhstan state university & State \\
\hline 6 & Pavlodar State Pedagogical University & State \\
\hline 7 & H. A. Buketov Karaganda State University & Private \\
\hline 8 & Academic innovative university (AIY) & Joint stock \\
\hline 9 & Kazakh Academy of Sport and Tourism & \\
\hline
\end{tabular}

We assume that analysis of graduate course in "Physical culture and sport" should be done on the example of Kazakh Academy of Sports and Tourism. Over the last 3 years, the academy has been ranked first in annual national rating of higher educational establishments of the Republic of Kazakhstan done by Independent agency for education quality assurance (IQAA) for graduate course in "Physical culture and sport" (2018) (see Fig. 2).

Based on regulation "On procedure for transfer of academic credits of the Republic of Kazakhstan into ECTS credits", ECTS credits are based on student's working hours needed for achieving desired results in education. One credit corresponds to 30 academic hours. 
sciendo Порівняльна професійна педагогіка 9(4)/2019 Comparative Professional Pedagogy 9(4)/2019

Curriculum for 7M01402 "Physical culture and sport" is aimed at training of highly qualified, competitive academic staff needed at labor market, able to realize professional activity at a high scientific and pedagogical level under social and economic conditions. This staff has systemized knowledge in the sphere of physical culture and sport and can use innovation technologies in professional sphere. The curriculum comprises 120 ECTS credits and envisages competence approach. Training can be done in Kazakh or Russian language (student's choice) (2019).

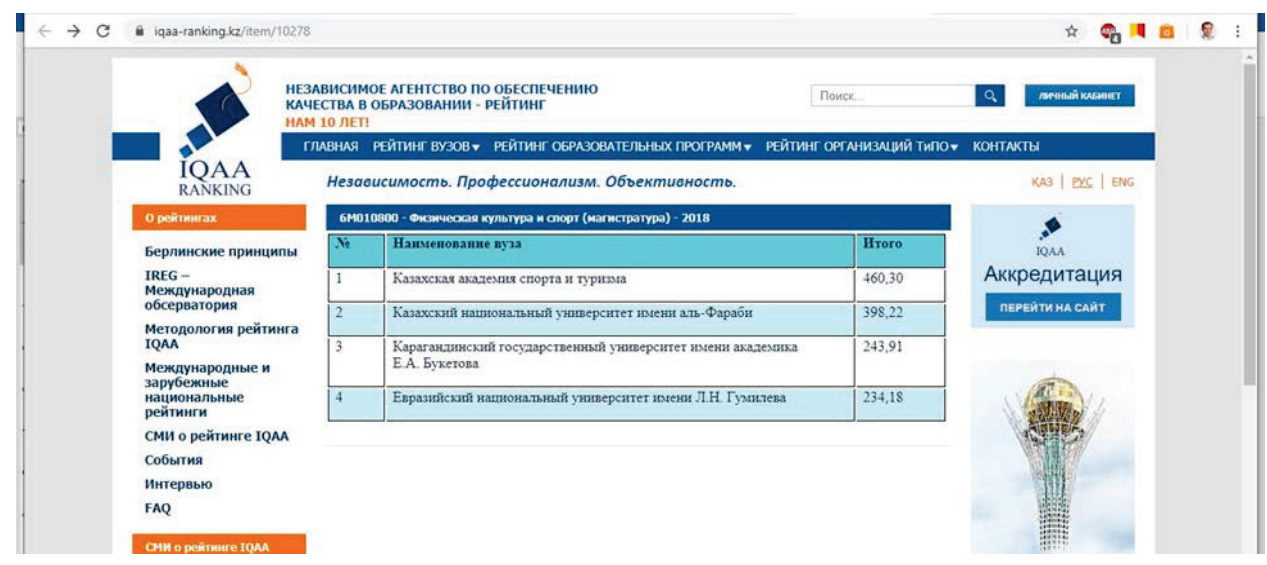

Fig. 2. Official Internet source of the National Agency for Quality Assurance in Education

Master students study the following subjects:

- cycle of fundamental subjects (components of a higher educational establishment and optional subjects);

- cycle of profile subjects (components of a higher educational establishment and optional subjects) (see Table 2).

Table 2

Subjects of graduate course by scientific and pedagogical area in "Physical culture and sport"

\begin{tabular}{|c|c|c|}
\hline No & Name of the discipline & ECTS \\
\hline \multicolumn{3}{|c|}{ Cycle of fundamental subjects (components of a higher educational establishment) } \\
\hline 1 & $\begin{array}{l}\text { History and philosophy of science / } \\
\text { Ғылым тарихы мен философиясы GTF5201/ IFN 5201/ HPS } 5201\end{array}$ & 4 \\
\hline 2 & $\begin{array}{l}\text { Foreign language (professional) / } \\
\text { Шетел тілі (кәсіби). ShT 5202/ IYa 5202/ FL } 5202\end{array}$ & 4 \\
\hline 3 & $\begin{array}{l}\text { Pedagogy of higher education /Жоғары мектеп педагогикасы. } \\
\text { ZhMP 5203/ PVSh 5203/ PHE } 5203\end{array}$ & 4 \\
\hline 4 & $\begin{array}{l}\text { Psychology of management / Басқару психологиясы. } \\
\text { BPsu 5204/ Psu 5204/ PsyM 5204 }\end{array}$ & 4 \\
\hline \multicolumn{3}{|c|}{ Cycle of fundamental subjects (optional subjects) } \\
\hline 5 & $\begin{array}{l}\text { Marketing of physical culture and sport / Дене шынықтыру және спорт } \\
\text { маркетингі. DShSM 5205/ MFKS 5205/ MFCS 5205 }\end{array}$ & 5 \\
\hline 6 & $\begin{array}{l}\text { The planning and organizing sporting events / } \\
\text { Спорттық іс-шараларды жоспарлау және ұйымдастыру. }\end{array}$ & 5 \\
\hline
\end{tabular}


sciendo Порівняльна професійна педагогіка 9(4)/2019 Comparative Professional Pedagogy 9(4)/2019

\begin{tabular}{|c|c|c|}
\hline No & Name of the discipline & ECTS \\
\hline 7 & $\begin{array}{l}\text { Management of physical education and sports/ Дене мәдениеті және } \\
\text { спорт менеджменті. DMSM5206/ MFKS5206/ MPES } 5206\end{array}$ & 5 \\
\hline 8 & $\begin{array}{l}\text { Psychological control in physical education and sports / } \\
\text { Дене шынықтыру мен спортты психологиялық бақылау } \\
\text { DShSPB 5206/ PKFKS 5206/ PCPhCS 5206 }\end{array}$ & 5 \\
\hline 9 & $\begin{array}{l}\text { Adaptive physical education in the system of rehabilitation of students } \\
\text { with special educational needs / Ерекше білім беру қажеттіліктері бар } \\
\text { студенттерді оңалту жүйесіндегі бейімдік дене тәрбиесі. } \\
\text { EBBKSOZhBT 5207/ AFKSRSOOP5207/ APESRSSEN 5207 }\end{array}$ & 5 \\
\hline \multicolumn{3}{|c|}{ Cycle of profile subjects (components of a higher educational establishment) } \\
\hline 10 & \begin{tabular}{l|} 
Scientific and pedagogical bases of physical culture and sports / \\
Дене мәдениеті және спорттың ғылыми-педагогикалық негіздері. \\
DShSGPN 5301/ NPOFKS 5301/ SPBPhCS 5301
\end{tabular} & 4 \\
\hline \multicolumn{3}{|c|}{ Cycle of profile subjects (optional subjects) } \\
\hline 11 & $\begin{array}{l}\text { Modern biotechnologies of management by sport preparedness / } \\
\text { Спорттық даярлылықты басқарудың заманауи биотехнологиялары. } \\
\text { SDBZB 6308/ SBUSP 6308/ MBMSP } 6308\end{array}$ & 4 \\
\hline 12 & $\begin{array}{l}\text { Methodological bases of scientific research in physical culture and sport / } \\
\text { Дене шынықтыру мен спорттағы ғылыми зерттеудің әдіснамалық } \\
\text { негіздері. DShSGZAN 6309/ MONIFKS6309/ MBSRPCS } 6309\end{array}$ & 4 \\
\hline 13 & $\begin{array}{l}\text { Innovative technologies of teaching in higher education / Жоғары } \\
\text { мектептегі оқытудың инновациялық технологиялары. } \\
\text { ZhMOIT 6309/ ITOVSh 6309/ ITTHE } 6309\end{array}$ & 5 \\
\hline 14 & \begin{tabular}{l|} 
Sport adaptology / Спорттық адаптология. \\
SA 5305/ SA 5305/ SA 5305
\end{tabular} & 5 \\
\hline 15 & $\begin{array}{l}\text { Pedagogical and medical--biological control is in the system of preparation } \\
\text { of sportsmen / Спортшыларды даярлау жүйесіндегі педагогикалық } \\
\text { және медицина-биологиялық бақылау. } \\
\text { SDZhPMBB 5306/ PMBKSPKS 5306/ PMBCSPS } 5306\end{array}$ & 5 \\
\hline 16 & $\begin{array}{l}\text { Sports and improving technologies in mass sport / } \\
\text { Бұқаралық спорттағы дене шынықтыру-сауықтыру технологиялары. } \\
\text { BSDShST 5303/ FOTMS 5303/ SITMS 5303 }\end{array}$ & 5 \\
\hline 17 & $\begin{array}{l}\text { Technology of critical thinking development / } \\
\text { Сыни ойлауды дамыту технологиясы. } \\
\text { SODT 6308/ STRKM 6308/ TCTD } 6308\end{array}$ & 4 \\
\hline 18 & $\begin{array}{l}\text { Theoretical and methodical bases of youth sport / } \\
\text { Жасөспірімдер спортының теориялық және әдістемелік негіздері. } \\
\text { ZhSTAN 5304/ TMOJuS 5304/ TMBYS } 5304\end{array}$ & 5 \\
\hline 19 & $\begin{array}{l}\text { The theory, method and practice of the chosen sport (in the sports } \\
\text { organizations and sports of the highest achievements). Specialization. / } \\
\text { Жоғары оқу орындарында (жоғары жетістіктер спортында) таңдаған } \\
\text { спорт түрін оқыту, теориясы әдістемесі және практикасы. Мамандандыру. } \\
\text { ZhOOTSTOTAP 5302/ TMPIVS 5302/ TMPCS 5302 }\end{array}$ & 5 \\
\hline
\end{tabular}

It should be noted that subjects taught to master students by pedagogical curriculum in Kazakh Academy of Sports and Tourism mostly correspond to the subjects taught at "Secondary education. Physical culture" in Ukraine. 
One of the elements of educational process of masters training in Kazakh Academy of Sports and Tourism is practice (pedagogical and research) held at the second year of studies. The aim of pedagogical practice is to train master students to work in comprehensive establishments, colleges, higher educational establishments. Practice is organized at departments that graduate students. Together with academic advisors, students choose a subject to teach independently with its further analysis. Student's activity within this practice envisages formation and development of theoretical thinking, strategic view of a situation, ability to independently lead a group. Research practice envisages acquisition of experience in research of an urgent academic issue to solve real practical tasks. During practice students are engaged in collection, processing, analysis, and systematization of scientific information related to the topic in order to write a thesis; make a plan of research work; thoroughly study the chosen topic.

Upon completion of studies, students are awarded the degree of a master in pedagogical sciences in "Physical culture and sport". The spheres of professional activity of such masters are as follows: doing educational, sports, mass, and health-improving work as a teacher of physical culture and physical education.

\section{CONCLUSIONS}

In the Republic of Kazakhstan, fundamental academic education in "Physical culture and sport" is obtained at graduate course. Training at graduate course is done on the basis of higher education curricula in two areas: scientific and pedagogical (at least two years) and profile (at least one year), full time only.

Graduate-course program by academic and pedagogical area in "Physical culture and sport" in the Republic of Kazakhstan corresponds to graduate-course program in "Secondary education. Physical culture" in Ukraine.

Second-level educational program in "Physical culture and sport" includes cycles of basic and profile subjects that are further divided into components of a higher educational establishment and optional subjects.

Completion of this curriculum provides formation of highly qualified, competitive academic and pedagogical staff needed at labor market, able to act professionally in any social and economic situations at a higher academic and pedagogical level.

Prospects for further studies include a comparative analysis of the professional training of future masters in physical culture in Ukraine and the Republic of Kazakhstan.

\section{REFERENCES}

1. Analytical report on realization of the Bologna process principles in the Republic of Kazakhstan. (2018). Astana: The Bologna Process and Academic mobility Center.

2. Akhmetzhanov, S., Tusupbekov, B., \& Tileubergen, D. (2016). Higher education in Kazakhstan: issues and development perspectives. Bulletin of KazEU, 4, 117-124.

3. Dereka, T. H. (2016). Features of professional training of specialists in physical education in the CIS, EU and USA. Perspective directions of development of modern science, $8,48-50$.

4. Humeniuk, S. V. (2017). Features of professional training of specialists in the field of physical culture and sports at universities of Western Europe. Bulletin of Lviv University. The pedagogical series, 32, 419-425.

5. Independent Agency for Quality Assurance in Education. (2019). Retrived from https://iqaa-ranking.kz/. 
sciendo Порівняльна професійна педагогіка 9(4)/2019 Comparative Professional Pedagogy 9(4)/2019

6. Kazakh Academy of Sports and Tourism. (2019). Retrieved from http://kazast.kz/.

7. Ministry of Education and Science. (2019). Retrieved from http://www.edu.gov.kz/ $\mathrm{ru} /$ index.php.

8. On approval of state general education standards for respective levels of education: The Republic of Kazakhstan government decree. No 1080. (2012).

9. Pavelko, Yu. (2011). Scientific potential of the sports field in the leading countries of the world. Retrieved from http://www.nbuv.gov.ua/old_jrn/soc_gum/tmfvs/text s/2011_2/files/art_32.pdf.

10. Sagintayeva, A., Hartly, D., Ekel, P., \& Zhakypova, N. (2018). Corporate management: higher educational establishments of Kazakhstan. Astana: Nazarbayev University Graduate School of Education.

11. Svatiyev, A. (2012). Analysis of the state of higher physical culture education in countries in Western Europe and Asian-Pacific region. Academic Journal of Melitopol State Pedagogical University. Series: Pedagogy, 84-88.

12. The Ministry of National Economy of the Republic of Kazakhstan Statistics Committee. (2019). Retrieved from http://stat.gov.kz/official/industry/62/statistic/7. 